\title{
Application of Foresic Accounting: A Study of Companies in Nigeria
}

\author{
Aribaba, Foluso Olugbenga \\ Centre for Distance Learning \\ Obafemi Awolowo University, Ile-Ife, Nigeria. \\ foarib@yahoo.co.uk
}

Doi:10.5901/ajis.2013.v2n2p447

\begin{abstract}
This paper examined the application of forensic accounting to companies in Nigeria using the basis of whether those saddled with the responsibility of maintaining accountability in both the public and private sector really appreciate its importance. The results show that forensic accounting in Nigeria is still new and that its impacts are not well felt.
\end{abstract}

Key words: Forensic accounting, Forensic accountant, Fraud investigation, Forensic accounting services

\section{Introduction}

Forensic accounting is becoming one of the strongest growth areas in the accounting profession all over the world. Maurice Peloubet coined the phrase "forensic Accounting" in 1946. At that time Peloubet and co. in New York Peloubet stated that, during the War both the public accountant and industrial accountant have been in existence and are now engaged in the practice of forensic accounting. Peloubet suggested that until recently, forensic accounting is only practiced in the courtroom, and that the preparation of financial statements has some of the features of forensic accounting.

Forensic accounting as defined in the forensic accounting directory of the Florida Atlantic University (FAU) is "the practice of utilizing accounting, auditing and investigative skills to' assist legal matters. It encompassed two main areas:

Litigation support represents the financial presentation of economic issue related to existing or pending litigations. Investigation is the act of determining whether criminal matters such as employee theft; fraud (including falsification of financial statements), identify theft and insurance fraud have occurred.

In the western world, forensic accounting and investigation is gaining widespread awareness and acceptability in both the public organization and the private one. The collapse of Enron corporation, which is perhaps one of the most significant business events that has occurred in the last 50 years, has significantly awaken the need for a forensic accountant in fraud detection, using a forensic accounting techniques. Enron, which is ranked number 7 on the fortune 500 list doing 100 billon of business in year 2000 had its stock drop from more than $\$ 90$ to $\$ .25 \mathrm{~m} 14$ months. The Enron debacle has had a devastating effect on the business environment.

Stockholders and lenders have lost tens of billions of dollars and Enron's 20000 employees have seen their retirement savings evaporate. Come back home, Cadbury Nigeria will likely record a loss of \$15million on the year 2006(Shen-Hoorver, 2006).

The collateral damage in case of Enron continues to reverberate and

Punish those directly and indirectly involved. Enron's external auditor, Arthur Anderson, along with the accounting profession itself has been dealt with a crushing blow. Besieged by lawsuits from all sides and its reputation was shattered, its survival is very much in doubt, this is a big crisis in accounting profession today.

As a result, genuine effort is being made in focusing attention on fraud detection and the use of forensic accountants and fraud examiners to be on increase and diploma courses are available in most schools in U.S.A and Canada. Forensic accountants search for financial Shenanigans by using a mix of accounting law, computer technology, ethnics and criminology. An external auditor is expected to perform an assessment in accordance with generally accepted auditing standard for the purpose of rendering an opinion that the financial statements have been prepared in accordance with Generally Accepted Accounting Practices (GAAPS). A forensic accountant takes a more proactive approach to examining the books of a company. He is a specialist, who makes no assumption of management integrity 
and brings to evaluation process, less concern than an auditor with whether the report conform to generally accepted accounting practices (GAAP) and more interest in exposing any possibility of fraud. Since a forensic accountant often faced legal issues, an accountant practicing in the forensic area needs to have an understanding of the legal environment in which the business operate. This is because the evidence the forensic accountant derives from an investigation may require his or her testimony as an expert witness. The demand for the services of forensic accountants has increased in recent years. A United State News and world report cover story entitled "Sherlock Holmes, Meet Enron on February 18, 2002, ranked forensic accounting as the number one most secured career trade. The increasing cases of disputes in business environment and the growing incidence of fraud have contributed to the demand of litigation support services. Unfortunately, few accountants in the Nigeria economy have necessary knowledge of forensic accounting.

No doubt, forensic accounting is yet to be developed; only few auditors in the international audit firms have carried out any serious forensic accounting assignments for clients. The increasing cases of fraud in Nigeria and around the world in the recent past has been alarming, emphasizing the invisibility of forensic accounting services. Sadly enough most of the fraud cases are not reported in Nigeria and there is a little statistics to show the trend.

The globalization of economics and information technology, such as electronic money transfers, have also eased the path of the fraudsters and complicated "the task of the investigators.

Nigeria, as a nation, operates in the same global economics and information technology arena. As a developing economy, the growths trend of the banking industry and the just concluded capitalization issue in the industry, there may be need for the services of the forensic accountant in the nearest future. As the industry expands, with the use of latest state- of - the art technology, the incidence of fraud is likely to increase as well. There will be growing need for the services of a forensic accountant. Hence the need for this research works.

In this work, the meaning' of forensic and investigative accounting will be examined. This will help creates the awareness of the significant use of a forensic accountant; and how he can help to prevent possible fraud in the nation's financial and non financial systems.

\section{Meaning of Forensic Accounting}

The Webster's dictionary defined 'Forensic" as belonging to use in, or suitable to a court of judicature of to the public discussion or debate. While Accounting is commonly defined as "the art of recording, classifying, summarizing and interpreting monetary transaction and event of a financial character". Izedomi (2000), defines auditing as an "Independent examination and expression of the financial statements of an enterprise prepared by the management of that enterprise, by an appointed person, called auditor, other is express a professional opinion whether financial statement show a true and fair view position of the enterprise as at the end of the financial period. Also, Oladipupo (2005), defines investigation as an "examination of the record and accounts of an organization for special purpose". The integration of accounting, auditing and investigation yield the specially known as forensic accounting.

Forensic accounting is viewed as the especially area of accounting that described engagement that result from real or anticipated litigation, (Wikipedia Encyclopedia, 2006). In holistic view, "these engagements fall into one of the four categories, economic damages, fraud and other forms of economic crime", as the use of investigative techniques, integrated with accounting to develop information and opinion for evidence in court and for use by expert witness. Also, forensic accounting is simply the process of interpreting, summarizing and presenting complex financial issues clearly of law as an expert witness. (Howard and Sheetz, 2006).

\section{The Forensic Accountant}

The forensic accountant could be called the "Bloodhounds" of the accounting profession, the nose -to-the - ground financial investigator who sniffs out complex fraud plots and other fiscal Shenanigans that often go undetected by the other 'breads' within the accounting field (Voght, 2003). A forensic accountant can be defined as someone who is applying financial skills and an investigative mentality to resolve issues, conducted with the context of the rules of evidence (Bologna and Linguist, 1995). His knowledge encompasses financial expertise, knowledge of fraud and a strong knowledge and understanding of business reality and the working to the legal system (Thornhirr, 1995).

Robert (1990), describe a forensic accountant as someone who can look behind/beyond their face, not accepting the record at their face value, someone who has a suspicious mind that the document he or she is looking at may not be what they purport to be, or someone who has the expertise to go out and conduct every detailed interviews of individuals 
to develop the truth. Forensic accountants search for financial Shenanigans by using a mix of accounting law, computer technology, ethics and criminology (Voght, 2003). Companies in Nigeria, even" Government ministries and parastatals operate in the same global economy and information technology environment, and as a result of the growth trend of the banking industry especially, there is therefore the need for services of the forensic accountant. The forensic accountant can be engaged in public practice or retain by lawyers, banks and insurance companies, the law enforcement agency, the court and the business community. A capable forensic accountant should, nevertheless possess certain characteristics, these include: independence, confidence, sound professional judgment, thoroughness, creativity and sensitive (Hills, 2004).

\section{Forensic Accounting Services}

Accounting to KPMG, (1995), the forensic accountant is often involves in the following activities;

\section{Fraud Awareness Workshop}

The workshops allow the forensic accountant to interact with a large member of people, in addition to this; client specific workshops are also conducted.

\section{Investigation}

The fraud, forensic accountant most likely encounters will depend on the nature of business and the way it is managed. Expenses and purchase are principal area of fraud, with false reporting of financial information and siphoning of funds are also relatively frequent. The most frequently frauds by employee involve the theft of cash or inventory, or submission of false expenses claims; cheque's forgeries are also very common. Due to the increased sophistication of fraud and the requirement of prior experience in conducting fraud investigation, organization have been able to realize that it is best for an expert who is independent and unbiased to conduct an investigation.

\section{Asset Tracing}

Tracing and identifying client assets that are the unlawful possession or control of third parties, gathering intelligence on the third parties and recovering of asset through civil remedies.

\section{Litigation support}

Forensic accounting services provide opinion on technical question of audit, accounting, taxation, or other areas. Litigation support involved quantification of losses in the context of fraud, disputed business valuation, loss of profits, insurance claims, intellectual property disputes and in many other situations.

\section{Business / Employee Fraud Investigations}

Business fraud investigation can involve funds tracing, asset identification and recovery, forensic intelligence gathering and due diligence reviews. Employee fraud investigations often procedures to determine the existence, nature and extent of fraud and may concern the identification of a perpetrator. These investigations often entail interviews of personnel who had access to the funds and a detailed review of the documentary evidence.

\section{Mediation and Arbitration.}

Because of their familiarity and comfort with legal issues and procedures, some forensic accountants have sought out special training and become involved in alternative dispute resolution (ADR). ADR services include both mediation and arbitration and are designed to help individuals and businesses resolve disputes with minimal disruption and in a timely fashion. 


\section{Approaches to a Forensic Accounting Assignment}

Each forensic accounting assignment is unique. Accordingly, the actual approach adopted and the procedures performed will be specific to it. However, in general, much forensic accounting assignment will include the steps detailed below:

\section{Meeting with the client}

It is helpful to meet with the client to obtain an understanding of the important facts and issues at hand.

2. Perform a conflict check

A conflict check should be carried out as soon as the relevant parties are established.

\section{Perform an initial investigation}

It is often useful to carry out a preliminary investigation prior to the development of a detailed plan of action. This will, allow subsequent planning to be based upon a more complete understanding of the issues.

\section{Obtain the Relevant Evidence}

Depending on the nature of the case, this may involve locating documents, economic reformation, assets, a person or company, another expert or proof of the occurrence of an event.

\section{Develop an Action Plan}

This plan will take into accounts the knowledge gained by meeting with the client and carrying out the initial investigation and will set out the objective to be achieved and the methodology to be utilized to accomplish them.

\section{Perform the Analysis}

The actual analysis performed will be dependent upon the nature of the assignment.

\section{Research Methodology}

The research design for this research work takes the form of a descriptive survey, as it uses one time only observation but involve as many variables as are necessary for the study. Both primary and secondary data were sourced for the purpose of answering and testing the hypotheses as well as building up literature review of the study. Primary data were sourced from professional accountant, professional auditors, financial analyst and captain of industries across every sectors of the economy in respect of the subject matter of study through the issue of 100 questionnaires on a judgmental sampling basis. Secondary data were also sourced from journals, textbooks and the internet.

Data generated from the administered questionnaires were analyzed verbally using descriptive statistical analysis, the mass information generated in this study was summarized in form of table and ratios. While the hypothesis were tested using inferential statistical, the chi square models.

\section{Results}

This study examines the application of forensic accounting to Nigerian Companies. The relevant data presented, analyzed and interpreted reflect the views of professional accountants, professional auditors and financial analysts.

100 questionnaires were administered, out of which 70, representing a response rate of $70 \%$ were responded to and returned, while 30 representing, $30 \%$ of the total questionnaire administered were not responded to. 
Table 1: Reliability, Transparency and Uniformity of the Financial Reporting Process

\begin{tabular}{|l|l|l|l|l|l|l|}
\hline & Strongly disagree & Disagreed & Undecided & Agree & Strongly agreed & Total \\
\hline Response & 8 & 15 & 7 & 17 & 23 & 70 \\
\hline Percentage & 12 & 21 & 10 & 24 & 33 & 100 \\
\hline
\end{tabular}

Source: Field Survey, 2013

Table 1 shows that, 12\% of the respondents strongly disagreed, 21\% were disagreed, 10\% were undecided while 24\% and $33 \%$ agreed and strongly agreed respectively. This indicates that the respondents are of the opinion that forensic accountant / forensic accounting can restore the reliability, transparency, and uniformity of the financial reporting process of Nigeria companies.

Table 2: The Need for Quality Service Delivery in Audit through Forensic Accounting

\begin{tabular}{|l|l|l|l|l|l|l|}
\hline & Strongly Disagree & Disagreed & Undecided & Agreed & Strongly & Total \\
\hline Response & 15 & 13 & 7 & 17 & 18 & 70 \\
\hline $\begin{array}{l}\text { Percentage } \\
(\%)\end{array}$ & 21 & 19 & 10 & 24 & 26 & 100 \\
\hline
\end{tabular}

Source: Field Survey, 2013

From table above, $21 \%$ of the respondents strongly disagreed, $19 \%$ were disagreed, $10 \%$ of the respondents while $24 \%$ and $26 \%$ were agreed and strongly agreed respectively. This indicates that there is a need for quality service delivery in the audit services in Nigeria companies through forensic accounting.

In the interpretation of the chi- square result, the chi- square test is one of the most popular non - parametric tests in statistics. It is also referred to as distribution free test statistics. The terms "distribution free" and non-parametric are used to describe the best because unlike other tests of hypothesis, it does not depend on some a prior assumptions about the parameters of the population from which samples 3re drawn. It offers comparisons between an observed frequency and the expected frequency obtained. Null hypothesis $(\mathrm{Ho})$ is the one that stands to disqualify the testing hypothesis while alternate hypothesis (Hi) confirms and accept the positive positions of the hypothesis.

\section{Hypothesis 1}

Ho: Forensic accountants does not provide wide range of services

Hi: Forensic accountants provide wide range of services Responses

\begin{tabular}{|l|l|l|l|l|l|l|}
\hline S/N & $\begin{array}{l}\text { Strongly } \\
\text { disagree }\end{array}$ & Disagreed & Undecided & Agreed & Strongly agreed & Total \\
\hline 1 & 8 & 15 & 7 & 17 & 23 & 70 \\
\hline 2 & 15 & 13 & 7 & 17 & 18 & 70 \\
\hline 3 & 2 & 5 & 18 & 16 & 29 & 70 \\
\hline 4 & 4 & 1 & 6 & 39 & 20 & 70 \\
\hline Total & 29 & 34 & 38 & 89 & 90 & 280 \\
\hline
\end{tabular}

Source: Field Survey, 2013 
We obtain the $X^{2}$ by obtaining the difference between the observed and expected frequencies, square each of these differences, divide each squared -differences by the expected frequency, and sum up all the foregoing to obtain its value.

From the chi- square table, we compare this observed value of $X^{2}=59.153$ with the table value for $V$ degree of freedom. We determine the degree of freedom from the responses table as follows: $V=d f=$ (number of rows -1 ) (Number of column - 1) from our table, $V=d f=(4-1)(5-1), V=3 \times 4=12$ degree of freedom.

Thus, we have calculated and found the degree of freedom to be 12 , we look up the $X^{2}$ table at the $5 \%$ significance level and $V=12$ degree of freedom. The relevant value is 21.026. This is the table value of $X^{2}$

The Decision Rule

Accept Ho if the observed / calculated is less than the table value of $X^{2}$. Otherwise, reject it and accept Hi.

Since the calculated value of $\mathrm{X}^{2}$, the $\mathrm{Ho}$ is rejected, and $\mathrm{Hi}$ is accepted. This shows that forensic accountants provide wide range of service in Nigeria.

\section{Hypothesis 2}

$\mathrm{Ho}$ : No challenges available in providing forensic accounting services in Nigeria.

$\mathrm{Hi}$ : There are challenges available in providing forensic accounting services in Nigeria.

Responses

\begin{tabular}{|l|l|l|l|l|l|l|}
\hline S/N & Very little extent & Little extent & Some extent & Great extent & Very great extent & Total \\
\hline 5 & 15 & 13 & 7 & 17 & 18 & 70 \\
\hline 6 & 9 & 25 & 17 & 11 & 8 & 70 \\
\hline 7 & 17 & 16 & 25 & 7 & 5 & 70 \\
\hline 8 & 8 & 15 & 7 & 17 & 23 & 70 \\
\hline 9 & 2 & 5 & 18 & 16 & 29 & 70 \\
\hline Total & 51 & 74 & 74 & 68 & 83 & 350 \\
\hline
\end{tabular}

We obtain the $\mathrm{X}^{2}$ by obtaining the difference between the observed, and expected frequencies, square each of these differences, divide each squared differences. By the expected frequency, and sum up all the frequency to obtain its value in (Appendix B)

From the chi- square table in (Appendix 6), we compare this observe value of $X^{2}=74.34$ with the table value for $V$ degree of freedom. We determine the degree of freedom from the responses table as follows:

$V=d f=($ number of rows -1$)$ (Number of column - 1) from our table, $v=d f=(4-1)(5-1), V=4 \times 4=16$ degree of freedom. Thus, we have calculated and found the degree of freedom to be 16, we look up the $X^{2}$ table at the $5 \%$ significance. Level and $V=16$ degree of freedom. The relevant value is 26.296 . This is the table value of $X^{2}$. This is table of $X^{2}$

\section{Decision Rule}

Accept the $\mathrm{Ho}$ if the observed /calculated is less than the table value of $\mathrm{X}^{2}$ otherwise, reject it and accept $\mathrm{Hi}$. Since, the calculated value of $X^{2}$ in (Appendix $B$ ) is greater than table value of $X^{2}$, the Ho is rejected, and $\mathrm{Hi}$ is accepted. This shows that there are challenges available in proving forensic accounting services in Nigeria.

\section{Hypothesis 3}

Ho: No need to engage forensic accountants in some legal proceedings.

$\mathrm{Hi}$ : There are needs to engage forensic accountants in some legal proceedings. 


\begin{tabular}{|c|c|c|c|c|c|c|}
\hline $\mathrm{S} / \mathrm{N}$ & Strongly disagree & Disagreed & Undecided & Agreed & Strongly agreed & Total \\
\hline 15 & 2 & 3 & 8 & 29 & 28 & 70 \\
\hline 16 & 1 & 1 & 9 & 18 & 41 & 70 \\
\hline 17 & 3 & - & 6 & 27 & 34 & 70 \\
\hline Total & 6 & 4 & 23 & 74 & 103 & 210 \\
\hline
\end{tabular}

We obtain the $X^{2}$ by obtaining the difference between the observed, and expected frequency is square each of these differences, divide each squared differences by the expected frequency, and sum up all the frequency to obtain its value. From the chi- square table, we compare this observe value of $X^{2}=77.09 . .1$ with the table value for $V$ degree of freedom. We determine the degree of freedom from the responses table as follows:

$V=\mathrm{df}=$ (number of rows -1 ) (Number of column -1$)$ from our table,

$\mathrm{V}=\mathrm{df}=(3-1)(5-1), \mathrm{V}=2 \times 4=8$ degree of freedom.

Thus, we have calculated and found the degree of freedom to be 8 . We look $\sim P$. the $X^{2}$ table at the $5 \%$ significance. Level and $V=8$ degree of freedom. The relevant value is 15.507. This is the table value of $X^{2}$. This is table of $X^{2}$

The Decision Rule

Accept the Ho, if the observed /calculated is less than the table value of $X^{2}$. Otherwise, reject it and accept $H i$.

Since, the calculated value of $X^{2}$ is greater than table value of $X^{2}$, the $\mathrm{Ho}$ is rejected, and $\mathrm{Hi}$ is accepted. This shows that there are need to engage forensic accountant in some legal proceedings.

\section{Conclusion}

\section{Summary of Findings}

This study was carried out to look at the applicability of forensic accounting services in Nigeria. After a careful analysis of the information gathered from the various source of information used, the following findings were evident.

i. The services of forensic accountant are of great relevance to the development of the nation, the need to ensure credible financial reporting.

ii. A lot of potentials exist for forensic accountant services in Nigeria, as the economy is becoming a global village, increase in financial crime and others social vices.

iii. The forensic accountant requires innovative and creature skills. The need to be proactive and stay relevant to the recent development in the world is essential.

iv. The services of forensic accountant are really in abeyance in Nigeria. The reason given for this situation is that the various provisions of our laws are not strictly followed. Moreover, forensic accountants and lawyers do not really farewell in Nigeria. This is because they may not be able to reach a compromise on the fee payable for the services of forensic accountant.

In conclusion, it is obvious that the impact of the services of forensic accountants in Nigeria is not well felt. However, the professional accountants and the legal practitioners are advised to Utilize this new opportunities to the fullest salvage our nation for the future generation. Also, the performance on the witness box is key to the success in forensic accounting. Therefore, we need to develop this area in students of professional institutes knowing full well that they might be called upon one day to defend opinions given in their report. 


\section{References}

Ajayi, B (2007), Cadbury: Nigerian enron: retrieved March 22, 2008 from: http: nigeriaword. Com /feature / publication /babsajayi $1121466 / \mathrm{html}$

Ashton , V. (2004), Going Undercover: focus on forensic Accounting" student Accounting - A Magazine for ACCA student, September, 2004.

Carnes, K and Gierlasinski N.(2001), "forensic Accounting Skill Will supply finally catch up to Demand" managerial Auditing journal, 16.6.

Chilver, G (2000), "The Criminal Elite" The sociology of white collar crime, \%e, NYL St. martins.

Cotton, D.L. (2002), fixing CPA ethics can be an inside job, Retrieved June 7, 2007, from: Htt: / www. Washongtonpost. com/ ac2/wpdyn /A50649- 2002:6

Etter, B. (2001), the forensic challenges of e- crime retrieved march 22, 2007, from: http:/ www.com./ achieves / fundamentals.

Forensic Audit Retrieved march 20, 2007, from; http / www. Forensic accounting .com

Izedomi, F.O.I (2000), Introduction to auditing, Benin - city Ambik press 1'st Edition 266 pp

KMPG, (1995), ' Forensic Accounting service' Retrieved May 25, 2008 from www. Forensicaccounting. Com.

Oaikhenam, H. E. and pickett, J.(2002), Financial crime Investigation and control, By: wiley and sons.

Ramaswany, V. (2005), corporate Governance and the forensic Accounting. The CPA journal. Retrieved June 10, 2008, from www Nysscpa /org / cpa journal /2005/305 / essentials /p. 68/ html.

Ronald, T, (2000), "Litigation Support" accounting for Damages, A framework for litigation support Retrieved June 16, 2007. f: www.accountingfor damages.com

Sage, G. (1999), Financial Investigation and forensic Accounting, BocaRaton, Fl CRC. Press.

Schiltz M. (1999), InvestigationWhite Collar crime: forensic Accounting Demystified, Retrieved March 16, 2008. from: http://www.investigation.com.

Schiltz H. (1993), Financial Shenanigans' How to detect Accounting Gommicks and fraud in financial Reporting By: MCGRAWHILL

Sheetz, M and Howard, S. (2006), forensic Accounting and fraud investigation for non Experts, New Jersey:John Wiley and sons, inc.

Shilvers, R. (2000), comtemporary Auditing, the CPA Journal,

Retrieved May, 2004. From: www.mysscpa/org./cpajournal/2000/305/essentials/p.68/html

The Canadian Institute of chattered accountants,(2001):proposal for the development of standard in investigative and forensic accounting, Discussion paper, Montreal, Quebec CICA.

The Webster's Dictionary: Retrieved March, 2008, from: http://www.forensicaccounting.com

Thornhill, W. T. (1995), forensic accounting: How to investigate Financial fraud, New York: Irwin.

Tosin, S (2007), Cadbury Nigeria sued by investor over Accounting. Retrieved June, 6 2008. From htt:/www.business. time online.co.uk/to/business/industry-sector/consume-goods-article 1499780. ece.

Varney, T. (2000), Computer forensic' Internal Auditing, Retrieved June, $17 \quad 2008 . \quad$ From: http://www.usdoji/criminal/cybercrime/unlawful.com

Voght, P. (2003), "forensic Accounting emerges as a hot field. Retrieved June 17, 2008. from http:www.rgl.com. 